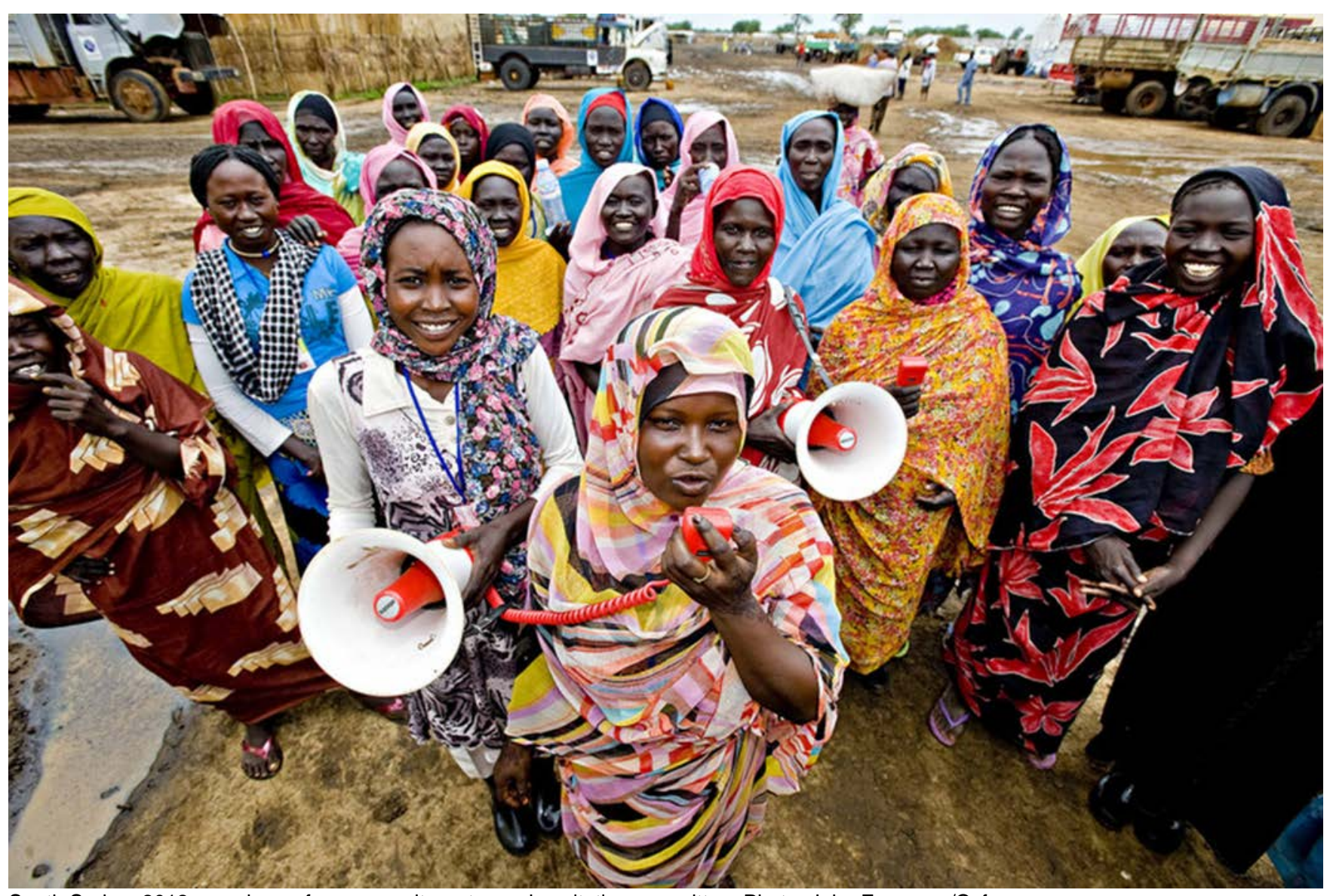

South Sudan, 2012: members of a community water and sanitation committee, Photo: John Ferguson/Oxfam

\title{
SPACE TO BE HEARD
}

\section{Mobilizing the power of people to reshape civic space}

The global trend of shrinking civic space mutes citizens' voices and threatens civil society's very existence. Without space to speak out, organize, and take action, progress on inclusive development is severely constrained. Citizens, civil society actors and their allies must formulate a strong and consolidated global response to defend our common space for engagement, debate and action. 


\section{SUMMARY}

The space for people to speak out, organize and take action against poverty, inequality and injustice is shrinking on a global scale. People in many countries around the world face serious restrictions and repression when exercising their basic rights. This includes citizens who raise their voices against corruption and political dysfunction, organizations that save lives and provide basic services to people in need, communities that defend their sustainable livelihoods and demand a fair share of natural resources, and activists who fight for gender justice.

The trend of shifting and shrinking civic space evolves differently in each country. Shrinking space can be driven by those who see their power and privilege threatened by civil society. It can be driven by those who attack the values that are fundamental for inclusive civic spaces, and by those who prioritize other interests over their professed concerns for civic space in international relations. Civic space is urgently needed by people to express and act on their interests and ideas; to navigate tensions and differences and to find commonalities. Civic space must be a vital ingredient for any strategy to protect national security, to foster development or to preserve social harmony. Yet many leaders misuse these objectives as a pretext to restrict rather than expand civic space. In many contexts, weak accountability structures and a changed development discourse negatively affect the ability of civil society to effectively defend civic space.

Yet there are also many initiatives around the world that have proven the power of people, of activists, civil society actors and their allies to resist the trend of shrinking civic space and to take advantage of shifts in civic space. Civic space can be protected, or even expanded, if citizens mobilize to defend their basic freedoms; if resilient and diverse civil society actors work together in strong alliances; if policy makers demonstrate political will to provide legal and political spaces; if global institutions uphold norms and accountability on civic space and if businesses respect and defend civic freedoms. It should be the highest priority for civil society and its allies to concentrate and combine individual efforts towards a consolidated global response to defend our common space for engagement, debate and action.

A note on the use of the term 'citizens': Not all people in the world are able to exercise their full citizenship rights. We use the term citizens in this paper as it implies a two-way relationship of duties and responsibilities between people and the duty bearers or decision makers who affect their lives. Civic space is one of the elements required to effect change where people are being denied their rights. 


\section{INTRODUCTION}

Creating a future that is secure, just and free from poverty: this is the vision that Oxfam shares with billions of people around the world. Turning it into reality requires active citizens who interact with accountable states and responsible businesses to create solutions that work for everyone, not just the privileged few. Civil society actors play vital roles to make this interaction work for people. As partners of states and businesses, civil society actors often provide inclusive basic services; they also play a watchdog role and exert pressure to demand accountability; and as advocates they defend the rights of marginalized people. It is the sum of these different roles, across a wide range of interest areas, which constitutes a vibrant civil society.

Yet the space for people to speak out, organize themselves and act against poverty, inequality and injustice in this way is shrinking around the world. In the last 12 years, political rights and civil liberties have been declining on a global scale. ${ }^{1}$ This has not reduced the commitment, courage and creativity of social movements, feminist groups, human rights defenders, individual activists and other civic actors to raise their voices. It does however make their activities more difficult, dangerous and in some cases even life-threatening. ${ }^{2}$

Shrinking civic space muffles citizens' voices and threatens civil society's very existence. Being deeply concerned about this, Oxfam joins forces with citizens, other civil society actors, and their allies to defend our common space. As civil society actors and global citizens, we cannot wait until there is no space left for our voices and actions. Any restriction on civic space threatens our basic rights as citizens. Shrinking space challenges our legitimacy as civil society actors to advocate for equality and justice. It undermines the social contract between citizens and governments. It reduces our ability to contribute to poverty reduction and inclusive development. It limits our means to effectively respond in a humanitarian crisis. Fundamentally, shrinking space challenges our collective power as people to determine our own futures.

Defending civic space is not the responsibility of only one part of civil society such as human rights organizations or activists. It is the diversity, breadth and vibrancy of civil society that has the potential to successfully reclaim and create civic space. Committed and coordinated actions from activists, academics, journalists, civil society organizations, progressive policy makers and other allies are needed to reverse the trend of shrinking civic space.

This paper outlines the analysis and strategic focus which inform Oxfam's contribution to the global defence of civic space. Based on an analysis of the main global drivers of shrinking civic space, we outline four key changes that we believe are necessary to reclaim and create civic space. The paper ends with some key principles and an open invitation to every civil society organization, donor, government, business and individual who subscribes to these same principles to join our common struggle to protect, defend and expand civic space. 


\section{SHRINKING CIVIC SPACE: A THREAT TO INCLUSIVE DEVELOPMENT}

\section{The concept of civic space}

'Civic space' refers to the structures, processes and legal instruments, and the absence of restrictions, that make it possible for citizens to associate, organize and act on issues of interest to them in the space outside the family, the state and the market. Civic space is crucial for civil society to survive and flourish. If there is space, being part of civil society allows people to express and negotiate their interests, values, and identities; to claim their rights and hold power-holders accountable; to improve their own lives and influence developments in their societies; and to engage with others in a peaceful way. People can participate in civil society as, for example, an individual activist or independent journalist or in association with others in community-based organizations, NGOs, labour unions, religious associations, social movements, grassroots initiatives, and other groups.

Recent years have seen a trend towards the shrinking of civic space in countries all over the world. Between June 2016 and September 2017, the global CIVICUS Monitor captured 292 incidents in which activists were detained and 304 in which they were harassed or intimidated; 184 attacks on journalists; 181 cases in which excessive force was used against protestors; and the adoption of legislative restrictions in 72 cases. ${ }^{3}$ Given that these numbers capture only incidents that have been reported to the monitor, the real numbers are likely to be even higher.

The trend of shrinking civic space cuts across authoritarian states and democracies, spanning all major regions in the global North and South. ${ }^{4}$ While the trend is global, its specific manifestation and dynamics are determined at national and local levels. Delving into country contexts also helps to develop a more nuanced understanding beyond the general 'shrinking space' diagnosis. Except for a few countries, space is rarely shrinking on all levels and for all agendas and actors at the same rate.

In some countries, state authorities try to restrict groups that challenge government or elite politics, while encouraging groups that support them. In other countries, governments accept the presence of international development organizations but actively and sometimes violently suppress local, more critical groups and activists. In highly patriarchal societies, female activists experience attacks both because they are outspoken citizens and outspoken women. Discriminatory gender norms are often strategically mobilized to stifle women's dissent. $^{5}$

Civil society organizations benefit from policies and regulations that ensure that they are held to the same standards of professionalism, accountability and transparency that they demand of others. Yet in many contexts, civil society regulations do not provide a neutral legal framework but are applied selectively to silence critical voices. In addition, bureaucratic requirements are often disproportionate to the size of organizations and activities that they regulate. In particular, small local organizations and loosely organized community groups 
struggle to comply with extensive administrative requirements and complex bureaucratic frameworks. As restrictions on organizations usually coincide with or follow harsh repression of protests and media freedom, citizens lose any space to speak out and act on their concerns.

Working in close cooperation with local civil society organizations and individuals around the world, Oxfam experiences the effects of shrinking and shifting civic space in its daily work. Shrinking civic space threatens progress on poverty reduction, rights-based development and all of Oxfam's core aims: the right to be heard, the right to life and security, the right to a sustainable livelihood, the right to an identity, and the right to essential services. ${ }^{6}$

\section{THE RIGHT TO BE HEARD}

The global trend of shrinking civic space constitutes a systematic denial of people's basic human rights to freely express themselves, associate with others, access information and peacefully assemble. State authorities around the world restrict the space of their citizens or of certain population groups, to expose social problems and political dysfunctions, to express their concern about ongoing developments and to propose alternative solutions for their country. Consequently, people are denied a voice in determining the course of their own lives and futures.

For marginalized people, space to express themselves and claim their rights has always been limited and highly contested. Civil society organizations that succeed in establishing genuine grassroots links can play a significant role in amplifying marginalized voices. Yet this role is increasingly challenged. Governments attempt to delegitimize critical organizations by labelling them as 'anti-national', 'politically motivated' or 'foreign agents'. Outspoken organizations risk being charged with failing to comply with disproportionate bureaucratic requirements, being deregistered or having their assets frozen.

A Ugandan example shows that the freedoms of speech, expression, and association can be immensely violated by deliberate actions of the state to restrict civic space. When people took to the streets in August 2017 to protest two amendments to existing clauses in the Constitution, civic space closed quickly. People were arrested and the offices of five civil society organizations were raided. About 29 organizations were required to respond to impromptu administrative requests for documents. Personal bank accounts for one organization's staff and bank accounts for two organizations were frozen.

The two disputed laws would remove safeguards for people during land acquisition and remove the age limit for the president. The amendment on the age requirements for a presidential candidate was adopted in December 2017. While research showed that $85 \%$ of the Ugandan people were against the removal of the presidential age limit, there was no space for people to express their discontent and for the media to freely share information on these issues. ${ }^{7}$

\section{THE RIGHT TO LIFE AND SECURITY}

Restrictions on civic space compromise the ability of civic actors to protect the rights of those who are displaced, at risk or in need of humanitarian assistance 
because of disaster, conflict, or insecurity. Effective humanitarian response requires direct access to the countries, areas and individuals affected. Yet in many countries, Oxfam has experienced that this access is increasingly restricted on political grounds and that burdensome administrative requirements limit the ability of civic actors to provide quick, effective and impartial relief to people in need.

This has been the case in Myanmar, for example, where Oxfam's humanitarian operations in Rakhine State have been severely disrupted through administrative restrictions and limited access to the region. ${ }^{8}$ Shrinking space for humanitarian assistance violates the rights of people affected by conflict and disaster to clean water, food, sanitation and other fundamental needs and increases vulnerability and insecurity.

\section{THE RIGHT TO A SUSTAINABLE LIVELIHOOD}

Increasing competition for land, water, food and energy sources, and the effects of climate change put increasing pressure on the livelihoods of people around the world, especially the most marginalized. The trend of shrinking civic space intensifies this problem. It impedes the ability of affected communities and activists to raise their voices against unfair practices of the government and private sector that jeopardize people's access to resources that are crucial for their survival.

In various countries around the world, Oxfam's staff, partner organizations and activists have faced threats, violence and prison terms when defending the land rights of poor farmers or demanding a fairer share of natural resources for local communities. At least 1,000 land and environmental defenders have been killed since 2010, while many more have been threatened, wrongly accused, attacked and imprisoned. ${ }^{9}$ This includes Oxfam partners and allies such as Berta Cáceres, Nelson García, and Lesbia Yaneth Urquia from the Civic Council of Popular and Indigenous Organizations (COPINH) in Honduras. All of them were assassinated in 2016 for defending the indigenous people's rights to sustainably manage and live off their land. ${ }^{10}$

\section{THE RIGHT TO AN IDENTITY}

Being a citizen entails both rights and obligations that are part of the social contract between citizens and their government. This includes the rights to speak out, organize and participate in decisions that affect the citizens' lives. Yet many governments restrict the basic rights of their citizens, which undermines the social contract. In addition, in many contexts, states deny certain population groups the status of formal citizenship as well as their fundamental rights. This leaves these groups without opportunities to determine their own futures and to participate in the affairs of the country they live in, and restricts their access to essential services and their freedom of movement.

Another core part of identity is sexuality and gender. Whenever diversity of sexuality and gender identity becomes the basis of discrimination, committed, courageous organizations and activists are needed to challenge the status quo. In most countries, these organizations and activists are on the frontline of shrinking 
civic space. Women human rights defenders and LGBTQI activists are facing threats and violence both because of their identity and the agenda they champion. These attacks come from both state officials and non-state actors, such as conservative civic groups or community members.

In 2016, the Tanzanian government banned HIV and Aids outreach projects that target gay individuals; forced the closure of US-funded programmes that provide medical services to the gay community; and closed private HIV clinics.

Concerned about the disastrous effects on Tanzania's LGBTQI community, a group of human rights lawyers and activists considered filing a case against the government for closing private HIV clinics. In October 2017, 13 people of this group were arrested and detained for 'promoting homosexuality'. This and similar incidents happening around the world create an atmosphere of fear among LGBTQI communities.

Attacks on organizations and individuals defending the rights and dignity of people with marginalized identities are not limited to sexuality and gender. This is demonstrated by cases in the Netherlands in which columnists have received death threats for commenting on racial discrimination in the Netherlands. ${ }^{11}$

As has been documented elsewhere, in certain contexts people in power attempt to maintain that power by suppressing dissenting and minority voices. ${ }^{12}$ This contributes to an atmosphere of intolerance and fear which can be manipulated to further stigmatize or attack vulnerable groups.

\section{THE RIGHT TO ESSENTIAL SERVICES}

Investing in essential services such as healthcare and education is a proven means to reduce poverty and inequality. ${ }^{13}$ Civil society organizations play a vital role in delivering these services to marginalized people, whenever governments are unwilling or unable to assume their responsibility to do so. Nevertheless, civil society organizations around the world find it increasingly difficult to provide much-needed essential services to the world's most marginalized people. Restrictions on foreign funding, public attacks and disproportionate administrative requirements drain the financial and human resources of civil society organizations to support marginalized communities. This is the case in India, for example, where the Foreign Contributions and Regulations Act requires civil society organizations to apply for special licences to receive funding from abroad. In 2016 and 2017, the applications of at least 32 civil society organizations to obtain a licence were denied, while thousands of organizations lost their licences due to a failure to comply with all administrative requirements. ${ }^{14}$

When the space for civil society organizations to provide essential services shrinks, any government's failure to provide free and inclusive public services can be disastrous. Yet in contexts in which space for service delivery is shrinking, the space for civil society actors to hold the government accountable is usually shrinking even more. Civil society organizations, activists and journalists that advocate for budget transparency and expose corruption face smear campaigns, censorship, intimidation and violence. ${ }^{15}$ If civil society and media are hindered in fulfilling their watchdog role, corruption and mismanagement are likely to increase. ${ }^{16}$ This leads to a lack of public resources needed to finance inclusive public services. 


\section{GLOBAL DRIVERS OF SHRINKING CIVIC SPACE}

How civic space is formed and develops at country level depends on an interplay of different national and local interests and power dynamics. These national dynamics in turn are influenced by regional and global trends. We have identified six global key drivers of shrinking civic space.

\section{Shifting balances of global power: the growing discourse of national sovereignty and non-interference}

We live in a multi-polar world where the traditional North-South divide is losing relevance and new centres of power are emerging. This includes not only the BRICS countries (Brazil, Russia, India, China and South Africa) but also other emerging markets countries such as Mexico, Indonesia, Nigeria, Pakistan, Turkey, South Korea and Vietnam. With the decreasing relevance of Western development aid, traditional champions of civic space and human rights among Western donors and multilateral institutions are no longer the sole guardians of global norms on civic space.

Governments around the world increasingly assert their power to push back against norms and practices that they see as undermining their national sovereignty ${ }^{17}$ - even if often to protect elites rather than truly national interests. The aid effectiveness agenda's emphasis on the importance of 'country ownership' for development has in some cases been used by recipient governments as justification for increased scrutiny and control of civil society receiving international aid funding, often particularly those with critical voices. ${ }^{18}$ Furthermore, in the last decade, some Western governments have increasingly prioritized other economic, political and security interests over their professed concerns for poverty reduction, civic space and human rights.

It is important that questions of civic space and other fundamental rights are decoupled from North-South (or East-West) polarization. Shrinking and shifting civic space affects countries all over the world, each with its own specific context for local civil society. Civil society is clearly not only or mainly a Western phenomenon. Various forms of associational life and civic participation are deeply rooted in all societies around the world, whatever the nature of their government. Originating in the Middle East, the existence of voluntary associations date back to at least 8,000 BCE and they are found on all continents. ${ }^{19}$ This invalidates attempts to brand civic space as an agenda of Western or other foreign governments.

\section{Rising inequality: political and economic elites cracking down on civic action that challenges powerful vested interests}

Shrinking civic space goes hand-in-hand with an increasing capture of state institutions by economic elites. The wealth of billionaires that derive profit from industries with close relationships to governments has increased significantly 
since the 1990s. ${ }^{20}$ Generous privatization deals, natural resources given away below fair value, corrupt public procurement, and tax exemptions and loopholes are all ways in which well-connected economic elites enrich themselves at the expense of the public. These economic elites can also use their influence on state institutions to restrict the space for civil society to hold governments and the private sector accountable for these practices.

In some respects, the crackdown on civil society can be seen as a backlash against civil society's successful advocacy and mobilization work. In the 1990s and 2000s, many civil society organizations shifted from service delivery to a rights-based approach and a focus on influencing policy processes. At the same time, social movements have proven their ability to bring together people from all strata of society, using new technologies and creative mobilization tactics to put pressure on those in power. However, as the influence and power of civil society has grown to challenge inequality and injustice, so has the desire on the part of those who profit from the status quo to restrict and control space for public debate and popular mobilization. ${ }^{21}$

\section{The changing nature of security: counter-terrorism and polarized societies}

Increased insecurity has had huge repercussions on civic space. The rise of ideologically driven violent groups, militarized responses to insurgency, conflicts in fragile contexts, terrorism and transnational crime have led to an increasingly dominant security agenda globally. In some cases, ideologically driven violent groups have created shell CSOs or misused existing CSOs to channel funding. ${ }^{22}$ This led the Financial Action Task Force (FATF), an intergovernmental body to fight money laundering and terrorist financing, to declare the non-profit sector as 'particularly vulnerable' to abuse. Governments have used the FATF recommendations to justify funding restrictions and overly burdensome administrative requirements for civil society groups. ${ }^{23}$

There is no statistical evidence indicating that CSOs are more vulnerable to abuse by ideologically driven violent groups than other non-state actors. Accordingly, the FATF removed this particular statement from its recommendations in $2016 .{ }^{24}$ Nevertheless, governments continue to use antiterrorism discourse to target legitimate civil society groups. ${ }^{25}$ In addition, security or public order laws have recently been adapted and applied in various countries that severely restrict and criminalize legitimate forms of civic engagement such as protesting. ${ }^{26}$ At the same time, many governments fail to adapt adequate security measures to protect civil society groups from attacks by ideologically driven violent groups.

New technology that provides new platforms and networks for activism has also allowed for new, expanded ways of control and surveillance of civil society. These restrictions have often been supported - or at least tolerated - by citizens who fear violence and terrorism. However, while economic, political and security interests have at times been allowed to override concerns about the rule of law, human rights, and civil society, suppressing dissent in the name of security has the opposite effect - deepening polarization and leading to less secure, more fragile societies. ${ }^{27}$ 


\section{Civil society legitimacy being questioned: weak accountability and missing links with citizens}

A weak public support base and lack of accountability have been important factors in undermining the position and strength of institutionalized civil society. Dependence on external donor funds has contributed to a perception that some non-government organizations are run by out-of-touch elites who are more accountable to donor requirements than to the people whose interests they claim to represent. Many institutionalized civil society organizations have failed to establish genuine links with citizens; to allow space for the younger generation in their own organizations; and to connect their own programmes and campaigns with broader social movements.

The use of private, for-profit contractors to implement donor-funded development programmes can further undermine the reputation of international development actors if such companies are perceived to profit from poverty. In addition, several kinds of groups and organizations have emerged that threaten to alienate citizens from civil society: so-called 'briefcase NGOs', ${ }^{28}$ 'government organized nongovernmental organizations' (GONGOs), ${ }^{29}$ and radical and ideologically driven violent groups that propagate intolerance and hate. These all compromise public perceptions of civic space as space for genuine citizen participation and representation.

All this has made it easy for people to feel as alienated from civil society organizations as they do from institutional politics. ${ }^{30}$ As a result, in many contexts governments do not face a coordinated and sustained public pushback when restrictions on civic space occur. Governments exploit this vulnerability through regulations to restrict the space for civil society to debate or to challenge their economic and political agendas. At one end of the spectrum they target individual activists who are isolated from institutional support structures, and at the other they pass restrictions on receiving foreign funding and impose specific, overly burdensome legal requirements for INGOs.

\section{Changing development discourse: questioning the integral value of civil society}

In the 1990s, the international donor community perceived support to civil society as an integral part of democracy promotion and thus as an end in itself. The discourse on civil society has changed in the last decade, and civil society participation is increasingly reduced to a means for national development and poverty reduction, primarily through service provision. Accordingly, some donors and governments have replaced grants for civil society organizations with contracts for implementing development programmes and delivering services in partnership with governments and the private sector. ${ }^{31}$

At the same time, the private sector is increasingly involved in implementing programmes with ODA funds and contributing to development goals as part of their core business or corporate social responsibility strategies. ${ }^{32}$ While the latter is a welcome trend, some donors and governments seem to perceive private sector engagement as an alternative to rather than complementary to civil society engagement. This limits the space and available resources for civil society, especially for actors with rights-based approaches and public advocacy strategies. 


\section{Populism, authoritarianism and nationalism on the rise: eroding the values of freedom, democracy and diversity}

We are witnessing threats to democratic political systems around the world. According to Freedom House, 2017 marked the twelfth consecutive year of a decline in global freedom. ${ }^{33}$ Right-wing populist political parties have influence across Europe, and populist leaders have won elections in countries as diverse as Hungary, the Philippines, and the United States. In other countries, partial democracies have been replaced by military regimes or other authoritarian governments. ${ }^{34}$

Populist and non-democratic leaders tend to be hostile, or at least suspicious, of both domestic and international civil society actors that advocate for democratic accountability, universal human rights, international solidarity and the rights of marginalized groups. ${ }^{35}$ Activities of NGOs to provide social services and relieve poverty are obstructed as they are perceived as counter to the leader's claim to be the sole provider of national progress and well-being.

Most authoritarian as well as populist leaders promote a nationalistic discourse, claiming to protect the 'national identity' and interests. Being part of the national identity is usually very narrowly defined, excluding people based on their ethnicity, cultural and religious background, skin colour, sexual orientation or political ideology. Similarly, national interests are equated with the leader's own interests. This discourse allows leaders as well as government supporters among media, civil society and the private sector to discredit civic actors that represent minorities or express dissent as threatening national unity and interests. ${ }^{36}$ 


\section{RECLAIMING AND CREATING CIVIC SPACE}

Around the world, Oxfam works together with local civil society actors and their allies to defend and expand civic space. Effective strategies are very contextspecific. In Oxfam's experience, strategies achieve most by focusing on one or several of the following key changes within a specific country context:

\section{CHANGE 1: PEOPLE'S SUPPORT FOR CIVIC SPACE}

Citizens around the world face repression when they raise their voices to challenge the status quo. At the same time, civil society organizations struggle to survive and achieve impact amid increasing civil and political restrictions. Although both individual people and civil society organizations suffer from shrinking civic space, civil society organizations have often not been able to connect their struggles to the lives of ordinary people.

To mobilize a strong and lasting public response when crackdowns occur, civil society organizations must ensure that they are recognized as legitimate actors by the wider public and have strong connections to citizens. Civil society organizations must build and strengthen their own accountability structures and ties to local constituencies and put civic engagement at the centre of their work. To help with this, civil society actors must practice transformative and feminist leadership that embodies the core principles and values of human rights, gender equality, participation, consultation and respect for the dignity of all people; they must be inclusive and allow for leadership renewal. ${ }^{37}$

Building stronger links with citizens will allow civil society organizations to promote narratives and develop initiatives that resonate with the struggles of ordinary citizens to reclaim civic space. It is important to understand and communicate that crackdowns on civic space do not just affect professional NGOs. Crackdowns also affect informally organized citizens' movements and local groups, as well as individual activists and journalists. In short, crackdowns affect everyone's ability to express their views and attain their rights.

Realizing this has led to an interesting initiative in India. In 2017, civil society organizations and media professionals joined forces to amplify the voices of people who are marginalized in mainstream civic spaces. The initiative includes media fellowships to cover the issues of marginalized people in creative and evidence-based ways, and financial support and training for grassroot activists and marginalized community groups.

It is crucial that civil society actors oppose any attempt to divide civil society into 'good actors' contributing to the national development agenda and 'bad actors' that defend democratic accountability and human rights. Instead, the contributions and legitimacy of a wide, diverse range of civic actors must be stressed in common narratives. This involves actively engaging with media and social media to better communicate civil society's contributions to positive 
change. It is important to stress that a healthy society needs space for both dialogue and dissent to mitigate conflicts, increase social cohesion and develop common solutions. In some contexts, well-known private sector companies, local celebrities, or community leaders can act as unusual and influential champions on civic space.

\section{CHANGE 2: STRONG CIVIL SOCIETY ACTORS}

In contexts of shrinking civic space, power holders attempt to control and restrict civil society actors. Therefore, civil society actors must adapt their ways of working and strengthen their internal structures to remain effective in restrictive environments. Oxfam proposes five areas that civil society actors should consider if they are to become more resilient and effective in contexts of shrinking and shifting civic space.

\section{Accountability}

Civil society organizations need to adopt the same transparency and accountability standards that they demand of others, both to governments and donors and to citizens and constituencies. Building grassroots legitimacy should go beyond minimum public engagement strategies towards transformational change in ways of working, involving constituencies and mobilizing people. Strengthening transparency and accountability reduces the likelihood of being wrongly accused of mismanagement, tax avoidance and fraud, and enables more effective responses when being discredited.

\section{Resilience and risk preparedness}

Civil society actors must be prepared for risks such as arrests and harassment of outspoken individuals, freezing of financial assets, attacks on the reputation of individual activists, civic groups and organizations, and other tactics to restrict their activities. This includes having effective risk management and holistic security skills and systems, budgets reserved for mitigation, prevention and emergencies, and strong support networks that provide access to legal, political and psychosocial support. Building the resilience of local civil society organizations can also mean diversifying their funding streams, including through domestic resource mobilization.

\section{Alliance building}

We have found that threats to civic space are most effectively addressed when diverse civil society actors join forces. ${ }^{38}$ Alliances should be as broad and inclusive as possible - including formal and informal civic actors with various identities, faith-based organizations, trade unions, media, universities, business associations, community groups, online activists and others. These alliances often need to be unbranded to provide space for diverse actors. Working in diverse alliances to protect and strengthen civic space enables civil society actors to protect the most targeted or vulnerable CSOs and activists; and to defend our common space more effectively. To do this well, we must adhere to the principles of feminist leadership and movement-building, including investing in strong capacities and mechanisms for managing internal differences. ${ }^{39}$ 


\section{New activism and tactics}

Civil society actors need to explore new strategies and tactics that are effective within shrinking and shifting spaces to contribute to transformative change.

Particularly, informal (youth) movements have shown high flexibility and creativity in exploring new ways and spaces to organize and express themselves. ${ }^{40}$ The International Youth Day 2017 gives a flavour of this creativity. A Café Politico in Honduras, a Facebook live programme with a top-level government official and rural youth in Bangladesh, a PechaKucha event in Somalia and an animation video to share the Global Youth Manifesto to End Inequality are only a few of the initiatives around the world to provide young people a platform to express themselves. ${ }^{41}$ Connecting to and learning from these actors can help more institutionalized civil society organizations refresh their ways of working so that they can still achieve their visions within contexts of shrinking and shifting spaces.

\section{Diversity and solidarity}

As civil society, we must ensure that our space is open for all people. This requires valuing diversity, expressing solidarity across groups with various identities and agendas, and challenging any forms of discrimination based on gender, age, sexual orientation, ethnicity, nationality, and other identity traits within our own ranks, the broader society and the government. Powerful international and national organizations must ensure that they do not take the space of less powerful or more critical activist groups. Influential organizations should instead use their power to give less powerful actors access to their networks and support them in building capacity to raise their voices.

An inspiring example can be found in Tunisia. Following increasing violence against individuals and associations among the LGBTQI community in 2015, the 'Collective of Individual Liberties' was formed, involving LGBTQI associations and activists as well as feminist and human rights associations. In 2016, the Collective supported the LGBTQI community in celebrating May 17, the World Day Against Homophobia and Transphobia. Turning from secrecy to an open event, the day was an important milestone for the LGBTQI community to create public awareness for their struggle.

\section{CHANGE 3: LEGAL AND POLITICAL SPACE}

National governments must develop and implement policies that provide an enabling legal environment for civic action and guarantee the rights to freedom of association, expression, assembly and information. Governments must also ensure space in political processes for inclusive citizen participation. Many power holders in national governments label civil society as a threat to what they perceive as national interests and lack the political will to create more space for different voices. This perception and narrative needs to be turned around, stressing the integral role of civil society within the social contract between diverse active citizens and effective states.

In addition to changing attitudes of power holders through a positive public narrative, dedicated strategies are needed to build political support for improved legal frameworks on civic space. Influence and pressure on government officials 
can come from multiple directions, including civil society, media, sometimes citizens on the streets, and sometimes global power holders and multi-

stakeholder fora. Depending on the context and type of actor, people can choose from a range of insider approaches, for example, engaging in discreet dialogue and influencing behind the scenes to create openness to change, and outsider approaches, such as public campaigns, media outreach or other public and visible influencing strategies.

The combination of different approaches has proven effective for a civil society alliance in Vietnam. The alliance, which is led by Vietnamese NGOs, convenes and coordinates among NGOs, the government, international organizations, donors and the public to promote people's participation, grassroots democracy and civic space. The alliance is currently advocating for the adoption of a progressive Law on Associations. While doing so, the group can build on its previous success. In 2015 and 2016, the alliance has been crucial to prevent the adoption of a more restrictive legal framework for associations. Using the strengths of its diverse network, the group was able to provide detailed comments and alternative proposals during the legislative process, while mobilizing public support through an online petition.

\section{CHANGE 4: GLOBAL NORMS AND ACCOUNTABILITY}

Global and regional norms, trends and actors influence national dynamics on civic space. It is thus crucial that regional and global actors and institutions from the global South and North actively uphold norms on civic space, prevent an erosion of those norms by power holders, and strengthen accountability for government commitments to civic space.

Multilateral institutions (e.g. the UN) and regional institutions (e.g. the African Union, the Inter-American Commission for Human Rights) should make strong public statements that civic space and citizen participation are essential pillars to achieve the Sustainable Development Goals (SDGs), to achieve peaceful and just societies, and to overcome increasing inequality and polarization.

Strengthening Southern champion governments on civic space and regional institutions like the African Union and the Inter-American Commission for Human Rights is particularly important to push back on perceptions that civic space is a Western-led agenda.

It is important that multilateral institutions, platforms and fora uphold and advance norms on civic space and hold their members accountable for their international obligations and commitments on civic space. Potential platforms include the Open Government Partnership (OGP), where many governments have signed up to commitments around key rights underpinning civic space; The High Level Fora on Aid Effectiveness, where rules in relation to aid flows and other sources of development finance are shaped that influence civic space dynamics; the Extractive Industries Transparency Initiative (EITI), that could prevent private extractives companies from restricting civic space in the areas of their operations; the European Union (EU), a traditional champion for human rights, which is at risk of ceding ground to hard security measures limiting civic space; and the World Bank, IMF, and regional development banks, which could use their economic weight in partner countries to protect civic space. Other key players are major 
bilateral and private donors which should provide political support for civic space and adapt their funding modalities for local civil society groups to promote their coping and response strategies.

It is also crucial that the private sector upholds global norms and accountability on civic space. The Business \& Human Rights Resource Centre documented 388 attacks on defenders and organizations working on business and human rights in 2017. ${ }^{42}$ Companies have extensively used defamation tactics and the legal system to criminalize the legitimate work of human rights defenders and civil society organizations. ${ }^{43}$ However, an increasing number of companies realise that their fates and those of civil society organizations are closely intertwined. ${ }^{44} \mathrm{~A}$ corrupt political system and judiciary, an environment of fear and mistrust and heavy obstacles to registration, operation and funding, are harmful for both business and civil society. These common concerns could result in increased cooperation between businesses and civil society actors to protect civic space. This could complement the actions of civil society actors to hold businesses accountable for their involvement in - or acceptance of - attacks on civic space.

\section{LOOKING AHEAD}

Shrinking civic space makes it more difficult, and in some contexts almost impossible for people to claim their rights to a better life, to advance gender justice and fight discrimination, to create and defend a sustainable livelihood, to gain access to essential services and to survive in times of crisis and disaster. As Oxfam's core purpose is to empower people to fight poverty and injustice, shrinking civic space threatens everything we do.

Nevertheless, civic space does not shrink in a linear way. Spaces are formed and shaped through the dynamic interaction of diverse actors. This gives civil society actors the chance to reclaim and create civic space and to renegotiate its constitution. This trend also provides opportunities: to build strong alliances and express solidarity with those at the forefront of civic activism; to strengthen links with citizens, foster participation of constituents and bolster accountability structures, as well as ensure that we practice what we preach in our relationships; to explore new spaces and influencing strategies; and to firmly anchor civic freedoms in the new global order. To summarize, as a country director of Oxfam has stated,

"We should not see "shrinking space as the new normal" that we need to adapt to. It is a historic moment of transition, where history can swing either way - we could be worse off, or we could get to something much better in the future.'

Diverse civil society actors have in recent years shared a glimpse of what this 'better future' might look like. This includes feminist organizations that practice transformative leadership; youth-led groups that have revived civic activism and political engagement of young people; local activists who have mobilized transnational public support through creative use of social media; and development and human rights organizations that have overcome their differences to work collectively for social change.

These are only a few examples of many that citizens, civil society actors and their allies could build on to reclaim and create civic space. The impact of this effort will 
very much depend on how civil society pursues the struggle for civic space: as a fight for one's own institutional survival or as a collective struggle about fundamental rights and everyone's ability to determine his or her future. While the first option leaves every actor isolated when crackdowns occur, the second has the potential to protect and even expand our common space.

\section{RECOMMENDATIONS}

Oxfam believes that reversing the trend of shrinking civic space requires committed actions and cooperation between local and global civil society actors, citizens, governments, multinational institutions, research institutes and universities, businesses, and others.

Shrinking civic space is a severe violation of human rights. It is also a threat to inclusive development and an obstacle for humanitarian aid. Shrinking space fuels conflict and increases fragility. It makes investments riskier and destroys livelihood options. It is impossible to reduce the defence of civic space to one of the traditional categories such as 'human rights protection' or 'development aid'. Shrinking civic space compromises Oxfam's core principles and must be of highest concern for everybody who shares these principles.

\section{Partnership}

Partnerships become meaningful if partners do not share only the positive results of their cooperation but also their risks and challenges. This is especially the case if one or several partners have less power and fewer resources to deal with risks than others. Solidarity among partners must go beyond the implementation of specific programmes and activities. Meaningful partnership requires concerted action whenever the rights of one partner are violated.

Partnerships should move beyond donor/grantee or strategic/implementing organization relations, towards equal partnerships. This includes respecting each other's autonomy and institutional identity, while creating dialogue and discussion to find common ground. Partnership modalities must reflect these principles by providing each other space and flexibility to make autonomous and accountable decisions. Leadership by Southern civil society groups is crucial to understand when and how global actors should take action, and when their role should rather be to encourage others to take the lead. To embrace social movements and people-driven initiatives, institutionalized civil society organizations must adapt their systems to be able to play the role of facilitators and catalysts.

\section{Empowerment}

People are empowered if they can determine their own future and feel confident that they can make change happen. To be empowered, people need both voice and space to speak out and act on their future. Yet this is unlikely to occur if authorities stigmatize and question the legitimacy of 'ordinary' people to raise their voice (their 'power within') and if powerful actors suppress people's collective action (their 'power with'). 
Creating enabling and empowering spaces requires that we defend the space for every citizen who wants to speak out and act, not just the space for institutionalized civil society. Organizations with more power and resources must be aware of their power and be careful not to take the space of activists and less formal groups. Successfully navigating the power dynamics behind shrinking and shifting civic space starts with a good understanding of one's own power in relation to others.

\section{Inclusiveness}

People feel included in their society if they feel that their needs and interests are recognized by decision making and if they can choose to participate in decisions that affect their lives. To participate meaningfully, people must be able to speak out without fear of repercussion and they need to have the space to organize with others to discuss and advance their interests and ideas, especially if these deviate from mainstream norms and the status quo. Governmental decisions and policies have better chances to be representative and sustainable when related decision making processes are transparent and consider diverse views and information. The suppression of discussion and dissent is often counterproductive, causing deeper polarization in societies and leading to less secure and more fragile societies.

Defending civic space must be an integral part of any strategy to champion inclusive development and support cohesive societies. Civic space cannot be reduced to the absence of restrictions. To create inclusive civic space, we must transform oppressive power dynamics that currently hinder marginalized people from being heard. This includes increasing financial, technical and moral support to people with marginalized identities and their organizations, and challenging patriarchal and other discriminatory attitudes, practices and policies within civil society, the private sector, the government and the wider society.

\section{Accountability}

To be a legitimate actor within wider society requires organizations such as Oxfam to give an account of their decisions and actions to citizens and other stakeholders. Transparent information is a precondition for informed debate and public accountability. We must also ensure that we take different perspectives into account when making decisions. This at a minimum requires us to consult the people affected by our decisions and operations. The more diverse the voices we consult, the more likely that we find a compromise that is accepted by many. This also includes listening to and respecting critical voices and alternative viewpoints. Lastly, we must accept that we are to be held to account. Citizens and other stakeholders have the right to urge us to take responsibility, both for our own commitments and for our obligations under national and international law.

\section{Integrity}

Civic space affects everything civil society does - and everything civil society does affects civic space. Civic space is a necessary and vital ingredient of any strategy to achieve sustainable development, inclusive economic growth, good governance, peace, stability and security and social cohesion. It is not an optional extra. Therefore, while working towards these goals, we must insist on the 
respect for, and inclusion of, civil society organizations and citizens that exercise their right to be heard. Civil society organizations must also consider how our own policies and practices contribute to the restriction or expansion of civic space for particular groups and integrate considerations for civic space into all our policies, strategies and operations. 
1 Freedom House (2018). Freedom in the World 2018. Retrieved from https://freedomhouse.org/sites/default/files/FH_FITW_Report_2018_Final_SinglePage.pdf

2 Front Line Defenders (2018). Annual Report on Human Rights Defenders at Risk in 2017. Retrieved from https://www.frontlinedefenders.org/en/file/4417/download?token=nNJxzC-E

3 CIVICUS (2017). People Power Under Attack: Findings from the CIVICUS Monitor. Ratings Update October 2017. Retrieved from https://monitor.civicus.org/Ratingsupdatesept17/

4 Freedom House (2018). Freedom in the World 2018. Retrieved from https://freedomhouse.org/sites/default/files/FH_FITW_Report_2018_Final_SinglePage.pdf

5 Women Human Rights Defenders International Coalition (2012). Global Report on the Situation of Women Human Rights Defenders. Retrieved from http://defendingwomen-defendingrights.org/wpcontent/uploads/2014/03/WHRD_IC_Global-Report_2012.pdf

6 Oxfam (2013). The Power of People against Poverty: Oxfam Strategic Plan 2013-1019. Retrieved from https://www.oxfam.org/sites/www.oxfam.org/files/oxfam-strategic-plan-2013-2019.pdf

7 Atrocities Watch Africa. (2017). Uganda Watch Update: 6-13 December 2017. Retrieved from http://atrocitieswatch.org/wp-content/uploads/2017/12/Uganda-Watch-Update-8.pdf

8 Oxfam (2017, September 8). Oxfam responds to urgent needs of people fleeing Myanmar conflict to Bangladesh [Press Release]. Retrieved from https://www.oxfam.org/en/pressroom/pressreleases/2017-09-08/oxfam-responds-urgent-needspeople-fleeing-myanmar-conflict

9 Global Witness (2017). Defenders of the Earth: Global killings of land and environmental defenders in 2016. Retrieved from https://www.globalwitness.org/documents/19122/Defenders of the earth report.pdf.pdf; Global Witness and the Guardian (2017). The Defenders: 188 environmentäl defenders have been killed so far in 2017 while protecting their community's land or natural resources. Retrieved from https://www.theguardian.com/environment/ng-interactive/2017/jul/13/the-defenders-tracker

10 A. Guereña and S. Burgos (2016). Unearthed: Land, Power and Inequality in Latin America. Oxfam. Retrieved from https://www.oxfam.org/sites/www.oxfam.org/files/file_attachments/bp-landpower-inequality-latin-america-301116-en.pdf; C. Ferreyra (2016). The Risks of Defending Human Rights: The rising tide of attacks against human rights activists in Latin America. Oxfam. Retrieved from https://www.oxfam.org/sites/www.oxfam.org/files/bn-el-riesgo-de-defender-251016-en.pdf

11 Nazar (2016). The Netherlands: Journalists face threats in heated Black Pete racism debate. Mapping Media Freedom. Retrieved from https://mappingmediafreedom.org/plus/index.php/2016/12/19/the-netherlands-journalists-facethreats-in-heated-black-pete-racism-debatel

12 Civicus (2018). State of Civil Society Report 2018. https://civicus.org/documents/reports-andpublications/SOCS/2018/socs-2018-overview_top-ten-trends.pdf

13 E. Seery (2014). Working for the Many: Public services fight inequality. Oxfam. Oxfam (2014). Retrieved from https://oxf.am/2FOCzE8

14 ICNL (2017). Civic Freedom Monitor: India. Retrieved from http://www.icnl.org/research/monitor/india.html; CIVICUS (2016, December 16). 7 more CSOs refused FCRA licenses in India. Retrieved from https://monitor.civicus.org/newsfeed/2016/12/16/7more-csos-refused-fcra-licenses-india/

15 CIVICUS (2017). People Power Under Attack: Findings from the CIVICUS Monitor. Ratings Update October 2017. Retrieved from https://monitor.civicus.org/Ratingsupdatesept17/

16 N.S. Themudo (2013). Reassessing the Impact of Civil Society: Nonprofit Sector, Press Freedom, and Corruption. Governance 26, 63-89; C. Magnoa and D. Gatmaytanc (2017). Corruption and civic space: Contextual factors influencing EITI compliance. The Extractive Industries and Society 4, 806-815.

17 T. Carothers (2015). The Deeper Struggle Over Country Ownership. In OECD, A Governance Practitioner's Notebook: Alternative Ideas and Approaches. Retrieved from https://www.oecd.org/dac/accountable-effective-institutions/Governance\%20Notebook.pdf

$18 \mathrm{Ibid}$; D. Rutzen (2015). Aid Barriers and the Rise of Philanthropic Protectionism. International Journal of Not-for-Profit Law 17(1).

19 D.H. Smith (1997). The International History of Grassroots Associations. International Journal of Comparative Sociology 38(3/4), 189-216.

20 D Hardoon, R. Fuentes Nieva, S. Ayele (2016). An Economy For the 1\%: How privilege and power in the economy drive extreme inequality and how this can be stopped. Oxfam. http://policypractice.oxfam.org.uk/publications/an-economy-for-the-1-how-privilege-and-power-in-theeconomy-drive-extreme-inequ-592643

21 T. Carothers and S. Brechenmacher (2014). Closing space: democracy and human rights support under fire. Carnegie Endowment for International Peace. Retrieved from http://carnegieendowment.org/files/closing_space.pdf 
22 FATF (2014). Risk of Terrorist Abuse in Non-Profit Organisations. Retrieved from http://www.fatfgafi.org/media/fatf/documents/reports/Risk-of-terrorist-abuse-in-non-profit-organisations.pdf

23 B. Hayes (2012). Counter-terrorism, 'policy laundering' and the FATF: Legalising surveillance, regulating civil society. Transnational Institute \& Statewatch. Retrieved from http://fatfplatform.org/wpcontent/uploads/2015/02/Legalising-Surveillance-Regulating-Civil-Society_Ben-Hayes.pdf;

24 FATF (2017). International Standards on Combating Money Laundering and the Financing of Terrorism \& Proliferation: The FATF Recommendations. Retrieved from http://www.fatfgafi.org/media/fatf/documents/recommendations/pdfs/FATF\%20Recommendations\%202012.pdf

25 CIVICUS (2017). Year in Review: International Governance. State of Civil Society Report 2017. Retrieved from https://civicus.org/documents/reports-and-publications/SOCS/2017/year-inreview/international-governance.pdf

26 See for example Amnesty International (2018). Spain: Tweet... If you dare: How counter-terrorism laws restrict freedom of expression in Spain. Retrieved from https://www.amnesty.org/download/Documents/EUR4179242018ENGLISH.PDF; Amnesty International (2018). France: A right not a threat: Disproportionate restrictions on demonstrations under the state of emergency in France. Retrieved from https://www.amnesty.org/download/Documents/EUR2161042017ENGLISH.PDF

27 B. Emmerson (2015). Report of the Special Rapporteur on the promotion and protection of human rights and fundamental freedoms while countering terrorism. United Nations General Assembly. Retrieved from

http://www.un.org/ga/search/view_doc.asp?symbol=A\%2F70\%2F371\&Submit=Search\&Lang=E; Wall, K. (2012). Addressing Violent Extremism: Creating Spaces for Civil Society Engagement. The Civil Society Network for Human Security. Retrieved from

http://www.humansecuritynetwork.net/documents/125374024/0/Report+of+the+June+26+Global+Conf erence+Addressing+Violent+Extremism

28 A briefcase NGO is formally registered as non-profit organization but is only set up to receive funding which goes into the pockets of those pretending to run the NGO. No reliable numbers exist that could indicate how widespread this phenomenon is.

29 A government-organized non-government organization (GONGO) is registered as non-government organization but controlled and often sponsored by a government in order to promote its political interests at home and/or abroad.

30 Edelman (2017). Edelman Trustbarometer 2017: Annual Global Study.

31 CIVICUS (2017). Thematic Overview: Civil Society and the Private Sector. Retrieved from https://www.civicus.org/documents/reports-and-publications/SOCS/2017/thematic-synthesis.pdf

32 OECD (2016). Development Co-operation Report 2016: The Sustainable Development Goals as Business Opportunities. Retrieved from http://dx.doi.org/10.1787/dcr-2016-en.

33 Freedom House (2018). Freedom in the World 2018. Retrieved from https://freedomhouse.org/sites/default/files/FH_FITW_Report_2018_Final_SinglePage.pdf

34 Ibid.

35 N. Galasso, G.N. Feroci, K. Pfeifer and M. Walsh (2017). The Rise of Populism and its Implications for Development NGOs. Oxfam. Retrieved from

https://www.oxfamamerica.org/static/media/files/The_Rise_of_Populism_and_its_Implications_for_De velopment_NGOs.pdf

36 CIVICUS (2017). Year in Review: New democratic crisis and civic space. Retrieved from http://www.civicus.org/documents/reports-and-publications/SOCS/2017/year-in-review/newdemocratic-crisis.pdf

37 For Oxfam's approach to Transformative Leadership for Women's Rights, see Oxfam (2014). Transformative Leadership for Women's Rights: An Oxfam Guide. Retrieved from https://d1tn3vj7xz9fdh.cloudfront.net/s3fs-public/file attachments/transformative-leadership-womensrights-oxfam-guide.pdf; Oxfam America (2017). Transformative and Feminist Leadership for Women's Rights. Retrieved from https://www.oxfamamerica.org/static/media/files/Transformative_and_Feminist_Leadership_for_Wome ns_Rights.pdf

38 R. Barahona (2017). How to carry out campaigns in a context of narrowing spaces and not perish in the attempt? Learning from Crece-Nicaragua. Oxfam; Oxfam \& CCP-AU (2016). Putting Citizens' Voice at the Centre of Development: Challenging Shrinking Civic Space across Africa. Pan Africa Policy Brief. Retrieved from https://www.oxfam.org/sites/www.oxfam.org/files/file_attachments/oxfampolicy-brief-civil-society-nov16_en.pdf

39 Oxfam (2014). Transformative Leadership for Women's Rights: An Oxfam Guide. Op. cit. Retrieved from https://d1tn3vj7xz9fdh.cloudfront.net/s3fs-public/file attachments/transformative-leadershipwomens-rights-oxfam-guide.pdf

40 See for example R. Youngs, et al. (2017). Global Civic Activism in Flux: Case studies from eight countries show how civic activism across the world is evolving and reveal crosscutting themes relevant to the future of civil society support. Carnegie Europe. Retrieved from https://carnegieendowment.org/files/Global_Civic_Activism_INT_Final_Full.pdf; Abujbara, J. et al. (2017). Beautiful Rising: Creative Resistance from The Global South. ŌR Books.

41 Oxfam (2017). International Youth Day 2017: Let's Trigger Change!. Retrieved from https://oxfamactiveyouth.org/international-youth-day-2017-lets-trigger-change/ 
42 Business \& Human Rights Resource Centre (2018). Key findings (Feb 2018). Retrieved from

https://www.business-humanrights.org/en/key-findings-from-the-database-of-attacks-on-human-rightsdefenders-feb-2017

43 Business \& Human Rights Resource Centre (2018). Business, Civic Freedoms \& Human Rights Defenders Portal. Retrieved from https://www.business-humanrights.org/en/bizhrds

44 Charities Aid Foundation (2016). Beyond Integrity: Exploring the role of business in preserving the civil society space. Retrieved from https://www.cafonline.org/docs/default-source/about-us-publications/cafbeyondintegrityreport-web-oct16v2.pdf 
(C) Oxfam International July 2018

This paper was written by Inga Ferber, with contributions from Barbara Oosters, Jo Rowlands and Araddhya Mehtta.

This publication is copyright, but the text may be used free of charge for the purposes of advocacy, campaigning, education, and research, provided that the source is acknowledged in full. The copyright holder requests that all such use be registered with them for impact assessment purposes. For copying in any other circumstances, or for re-use in other publications, or for translation or adaptation, permission must be secured and a fee may be charged. Email policyandpractice@oxfam.org.uk

The information in this publication is correct at the time of going to press.

Published by Oxfam GB for Oxfam International under ISBN 978-1-78748-309-5 in July 2018. DOI: $10.21201 / 2018.3095$

Oxfam GB, Oxfam House, John Smith Drive, Cowley, Oxford, OX4 2JY, UK.

\section{OXFAM}

Oxfam is an international confederation of 20 organizations networked together in more than 90 countries, as part of a global movement for change, to build a future free from the injustice of poverty. Please write to any of the agencies for further information, or visit www.oxfam.org

\author{
Oxfam America (www.oxfamamerica.org) \\ Oxfam Australia (www.oxfam.org.au) \\ Oxfam-in-Belgium (www.oxfamsol.be) \\ Oxfam Brasil (www.oxfam.org.br) \\ Oxfam Canada (www.oxfam.ca) \\ Oxfam France (www.oxfamfrance.org) \\ Oxfam Germany (www.oxfam.de) \\ Oxfam GB (www.oxfam.org.uk) \\ Oxfam Hong Kong (www.oxfam.org.hk) \\ Oxfam IBIS (Denmark) (www.ibis-global.org) \\ Oxfam India (www.oxfamindia.org) \\ Oxfam Intermón (Spain) \\ (www.intermonoxfam.org) \\ Oxfam Ireland (www.oxfamireland.org) \\ Oxfam Italy (www.oxfamitalia.org)
}

Oxfam Japan (www.oxfam.jp)

Oxfam Mexico (www.oxfammexico.org)

Oxfam New Zealand (www.oxfam.org.nz)

Oxfam Novib (Netherlands)

(www.oxfamnovib.nl)

Oxfam Québec (www.oxfam.qc.ca)

Oxfam South Africa

(http://www.oxfam.org.za/)

Observer:

Oxfam Turkey 